\title{
Agricultural Production and Trade Structure Profile in Democratic Republic of Congo (DRC)
}

J.- P. E. Lubanda ${ }^{1}$, L. Smutka ${ }^{1}$, R. Selby ${ }^{2}$

${ }^{1}$ Department of Economics, Faculty of Economics and Management, Czech University of Life Sciences Prague, Czech Republic

${ }^{2}$ Department of Management, Faculty of Economics and Management Czech University of Life Sciences Prague, Czech Republic

\begin{abstract}
The African region represents the weak point of the world economy. Many African countries have still not finished the process of transforming their economy. Agriculture represents only a minor portion of their economies' performance - however it is still a key sector of the economy (especially considering the number of people working in agriculture or people representing the agricultural population). The agricultural sector in many sub-Saharan countries is extremely sensitive and its stability affects the stability of the whole region. A very good example representing sub-Saharan Africa is the Democratic Republic of Congo (DRC). It is a country with a lot of potential, but it is classified among the poorest countries in the world. Its economy is extremely weak (despite its significant share in total GDP formation value), and underdeveloped. The share of agriculture in total GDP formation is over $42.5 \%$. The number of people living in rural areas represents over 45 million out of a total of 75 million. The number of people working in agriculture is over $60 \%$ of the total economically active population. The economy of the country is extremely poor and fragile, mainly because of political instability. The aim of this paper is firstly to specify the position of agriculture in the DRC economy, and also to specify the production and trade commodity structure in relation to other African countries. The paper's ambition is to identify the most perspective commodities (groups of commodities), both for production and also for trade, and to recommend such a production and trade profile which would allow the DRC the possibility of improving its competitiveness - not only in relation to other African countries, but also in relation to the global market. The production and trade commodity structures are analysed through the application of the BCG method and competitiveness analysis. In relation to these objectives, the paper provides the following conclusions. The position of agriculture in the DRC economy is stable one. Furthermore, agriculture probably represents the most stable part of the DRC economy. According to the portfolio and competitiveness analyses, the most important commodity items for the DRC are the following: Rice paddy, Maize, and Cassava. The most competitive trade items are particularly Coffee, Tea, and Cocoa, and Sugar Raw centrifugal. The most notable weakness of DRC agriculture is the production of Wheat, Beverages, Poultry Meat, and Fixed Vegetable Oils.
\end{abstract}

\section{Keywords}

WDRC, Africa, agriculture, production, trade, competitiveness, structure, comparison, value, development, trend, modified BCG matrix.

Lubanda, J.-P. E., Smutka, L. and Selby, R. (2016) “Agricultural Production and Trade Structure Profile in Democratic Republic of Congo (DRC) ", AGRIS on-line Papers in Economics and Informatics, Vol. 8, No. 2, pp. 67-87. ISSN 1804-1930. DOI: 10.7160/aol.2016.080206.

\section{Introduction}

Africa is a continent which consists of 54 states including some island states belonging to Africa (UN, 2011). The African population currently exceeds cc 1.2 billion inhabitants representing over $15 \%$ of the world's population. Population growth in the Africa region is (regarding the time series) a very dynamic indicator (Jeníček, 2011). Compared to other world regions, the African population is fast growing (Jeníček, 2010). From 1961 till 2015, it has grown from about 293 million to the current cc 1.2 billion. That means, an annual growth achieved cc $2.6 \%$ in average; this represents an increase of 15 million a year (on average). A peak of the population growth was achieved in the $1970 \mathrm{~s}$ and $80 \mathrm{~s}$, when the annual growth exceeded $2.8 \%$ (maximum $2.85 \%$ in 1982). In absolute terms, however, the peak of the population growth has come in the current 
decade, despite the decline in incremental growth (Jeníček, 2010). An annual increase of population by $2.1 \%$ in years 2014/2015 has turned into a decline in the relative growth rate; nevertheless an absolute increment has reached its historical highest value, represented by 24 million people. Such development far exceeds the population development in other continents. Another African specific is economic development (Ajakaiye and Ncube, 2010). Regardless of the amount of mineral resources and strong population basis, Africa is the poorest region (continent) of the global economy (Ahmed and Suardi, 2009). The total GDP value has been standing at a very low level in the long-term; expressed on per capita basis, the figures are remaining far below the world average. (Fosu, 2001). Currently, the value of African GDP reaches about USD 2.45 trillion which is a long way from results achieved in other regions (the value of world GDP has achieved USD 78 trillion in 2015). Taking into account the above mentioned share of Africa in the world population, and in the value of global product (about $3.1 \%$ ), essential abnormalities of economic development will appear. It should also be stressed that backwardness concerns not only the total GDP, but also GDP expressed on a per capita basis. While the average annual world GDP per capita reaches over USD 10 thousand, in the case of Africa, the value stands at around USD 2000. In this respect, it should be stressed that there are significant differences among African countries in terms of average levels of GDP per capita. While Equatorial Guinea has reached the GDP per capita of USD 18,389 in 2014, Democratic Republic Congo, in contrary, only USD 437 in the same year. Taking into account the more than 50 countries of African continent, only four of them exceed the average world GDP per capita. More than forty countries do not touch the level of USD 5,000 per capita, whilst 21 even reach the level of USD 1,000 (World Bank, 2016).

From an economic, cultural, social, as well as demographic perspective, Africa is far from being a homogenous continent (Fosu, 2003). Neither is the distribution of the GDP and population spread evenly. The African continent can be thus divided into several parts. From an economic point of view, it is reasonable to divide it into two main parts: North Africa and sub-Saharan Africa. North Africa, which consists of countries adjacent to the Mediterranean Sea, has undergone a different evolution. It has had historical ties mainly to Europe unlike the other African regions; its structure of population and related cultural, social, and other aspects varies significantly (Kuna, 2010). The population of North Africa is dominated by Arabs, whereas sub-Saharan Africa by the black population. About 200 million people live in North Africa, which is about one fifth of the total African population; over 900 million people are estimated to live in sub-Sahara.

A significant difference between the two parts of Africa lies in their economic performance. While the countries of North Africa generate about one third of the total African GDP (approximately USD 800 billion), the remaining two thirds (about USD 1.6 trillion) have their origin in the sub-Saharan region. There are also noticeable differences in the average GDP per capita between both regions (Akokpari, 2001).

The sub-Saharan Region is also characterised by the highest percentage of the population living below the poverty line. Currently, about $40 \%$ of the sub-Saharan population lives on less than USD 1.25 per day (World Bank, 2016). This is reflected in a high rate of malnutrition (Wodon and Zaman, 2010). Almost 200 million inhabitants of the region were confronted with malnutrition in the years 2009-2010. It should be underlined that the problem of malnutrition is a long-term problem of Africa (Kuna, 2010; FAO, 2010).

A very specific problem of Africa is its' economy structure (Jeníček, 2011). Africa is still heavily dependent on its agricultural sector performance. However within the world economy, GDP structure has almost finished the transformation process (over $70 \%$ is generated by services, cc $20 \%$ is represented by industry and less than $5 \%$ is represented by agriculture), in Africa - especially in its Sub-Saharan part the share of agriculture in total GDP formation is between $15-20 \%$. Even more, there are countries where the share of agriculture in total GDP formation is even higher than $30 \%$, and agriculture provides job opportunities for over $50 \%$ of population (Hopkins, 2014).

A very specific case in Africa is represented by the largest Sub-Saharan country and the fourth most populous African country - the Democratic Republic of Congo. DRC is a very specific country especially because of its population growth, increasing demand for food, very limited economy performance, and low level of society and political stability. We decided to choose this country as a very good object to analyse the extremes of African agriculture.

The Democratic Republic of Congo (DRC) is 
a country located in the centre of the African continent. The total area of the country is about 2,344,840 $\mathrm{km}^{2}$ (Global EDGE, 2014). The total agricultural area is about $260,000 \mathrm{~km}^{2}$. The agricultural area is very limited in comparison to the total country size, and the size of arable land is even lower: only about $70,000 \mathrm{~km}^{2}$. For historical reasons, the economy of DRC is extremely underdeveloped, and its performance is extremely low. Since its independence in 1960, the DRC went through numerous political and economic crises affecting its growth in general, particularly its economy and its agricultural production. These political issues caused many armed conflicts that mostly ended up with different sorts of wars (Ministry of Agriculture of DRC, 2012).

The structure of DRC's economy is dominated by primary sector performance. Agriculture is keeping a really dominant role. The share of agriculture in total GDP is estimated to be about $30-40 \%$. However, the share of agriculture in total GDP formation is very high, and agricultural production growth is very limited despite the significant population growth. In the period from 1960 to 2015, the DRC recorded population growth from about 15 million people to more than 77 million. The current inter-annual population growth is about three times higher in comparison to the country's real agricultural production growth, and two times higher in comparison to the country's total real GDP growth (The World Bank, 2016). The DRC is in a very complicated situation, as its process of economy transformation is still not finished. According to the most pessimistic material, published by USAID in 2015, agriculture accounts for 42.5 percent of the DRC's gross domestic product, employs 62 percent of its men and 84 percent of its women, and is the country's most promising foundation for establishing food security and sustainable, equitable economic development. For the last four years, the DRC has been ranked first on the Global Hunger Index, while agricultural production has fallen by 40 percent since 1990 . The average daily food consumption is estimated at less than 1,500 kilocalories per person, below the minimum of 1,800 per person required to maintain good health (USAID, 2015). However, the data provided by other institutions (e.g. FAO, WB or IMF) are not so pessimistic - though it is still true that the DRC is heavily dependent on the performance of the agricultural sector. The prosperity of the agricultural sector must be understood to be a key determinant in reducing poverty and stabilizing society. Agriculture is also the most stable sector of the DRC economy. It was "somehow" able to survive the period of civil wars and while the other economy sectors collapsed - agriculture is still working - but its effectivity is very limited.

There is no easy way for the DRC to solve its economy problems. The only way is to reduce its dependency on agriculture and to increase its agricultural sector performance and effectiveness. The next step is to encourage the growth of industry and the service sectors (Jeníček, 2010).

According to USAID, the only way to stabilise the DRC is to reduce poverty, to increase agricultural productivity, to improve market stability, and to encourage environmental sustainability. USAID proposed an integrated approach to stabilise the situation. The idea of this approach is to change the current agricultural production structure, to increase the productivity of the agricultural sector, and to reduce the number of farms operating in the DRC (USAID, 2015).

Agriculture as a key economy sector is a part of the huge development agenda introduced by the DRC government in recent years. That agenda is based on the following action plan.

For the period 2013 - 2020 the following five priorities areas were identified and programmes developed (DRC, NAIP, 2014):

Programme 1: Promote sustainable agricultural sectors, first and foremost food value chains, and develop agribusiness in order to improve the income of farmers and other operators in the sector;

Programme 2: Improve the management within the food and nutrition security and strategic reserves;

Programme 3: Develop and disseminate research products to users and improve the professional competence of the various actors;

Programme 4: Improving agricultural governance, promoting the integration of gender in the implementation of the Plan and the overall strengthening of sector-related human and institutional capacities;

Programme 5: Reduce vulnerability in the agriculture sector to climate change.

The strategic approach for the implementation of the NAIP is based on a number of principles for action (DRC, NAIP, 2014):

1) The inclusion and accountability of all public and private stakeholders involved in agricultural and rural development; 
2) Valuation of the comparative advantages of each province through the implementation of Provincial Agricultural Investment Plans whose development will be the responsibility of provincial authorities;

3) The establishment of Centres of Agricultural Enterprise (PEA) in order to boost the different sectors;

4) Mainstreaming gender aspects and good governance across all of the planned interventions;

5) Promoting and facilitating capacity building among all public and private stakeholders to enable them to perform their respective roles more effectively and efficiently; and

6) Focusing on the enhancement of agricultural productivity in a sustainable manner that also respects relevant environmental and social constraints.

To summarise the above mentioned text it is necessary to highlight the following: Agriculture is one of the most important drivers affecting the current economy development in the DRC. The share of services and industry in national economy formation is much lower that is typical for the other Sub-Saharan countries. Agriculture in the DRC must be understood as being a pillar of economy and society. Agriculture is considered to be the only safe pillar in their lives. However, agriculture in the DRC is very important, it is underdeveloped, and the living standards of people working in agriculture and their families is very limited. Their production performance is very low and their labour effectiveness is extremely low. The DRC suffers not only because of its limited agricultural production and agricultural sector's performance and productivity. It is also suffering because of its limited ability to compete with other countries both within the region and also outside. Agricultural production in the DRC is not as heterogeneous as is typical for other African countries. The DRC is heavily dependent on global agricultural price fluctuations, weather conditions and especially its' constantly increasing population. Population must be understood not only as a source of demand, it must be also understood as a source of many problems - thinking here about the structure and size of individual agricultural companies/farms. Despite the fact that in the past the DRC was considered as being a net exporter of agrarian products, nowadays the situation has changed. The DRC has lost its position of being a net exporting country, and it is now heavily dependent on imports. The DRC is losing not only its ability to produce enough food and to satisfy local demand, it is also losing its competitiveness. Competitiveness is disappearing not only at the level of inter-regional trade, it is also disappearing at the level of inter-regional trade. The situation is becoming more and more complicated, and the government is not able to solve the situation. The results is the crisis in the DRC economy and society. The proposed paper is focused on DRC agriculture. The main idea is to identify its structure (at the level of production and trade performance), and also to identify the main changes affecting its development (Maitah et al., 2014; Toth et al., 2014; Mikhalkina et al., 2015).

The aim of this paper is firstly to specify the position of agriculture in the DRC economy, and also to specify the production and trade commodity structure in relation to other African countries. The paper's ambition is to identify the most perspective commodities (groups of commodities) both for production and also for trade, and to recommend such a production and trade profile which would provide the DRC with the possibility to improve its competitiveness not only in relation to other African countries, but also in relation to the global market. The production and trade commodity structures are analysed through the application of the BCG method and competitiveness analysis.

\section{Materials and methods}

The paper is based on secondary data provided by UN Comtrade, FAOSTAT, World Bank and IMF. The analysed time period is from 2004 to 2012 (this time period was chosen because of data availability -2012 is the last year providing stable agricultural data in the case of all above mentioned databases). The paper is based on the application of standard statistical approaches and other methods (basic index, chain-index etc.). The paper is part of long term research published by one of the authors (Smutka). The paper is based on facts and findings already published in Smutka, Tomšík, (2011); Maitah and Urbankova, 2015; Maitah and Smutka, (2012); Tomšík and Smutka (2013); Smutka and Tomšík (2014). The agricultural sector performance is analysed through the gross agricultural production, and the agricultural sector's added value (as a part of GDP formation (Fuchs, 2013)).

This paper is focused especially on the study of the production and trade portfolio of the country compared to the production and trade situation of Africa as a region. However, before doing 
a modified BCG matrix (Smutka, 2011) analysis, the paper compares data for the year 2004 and 2012 of both the studied regions and identifies the 10 most important items (for commodity structure analyses, the standard FAO methodology is applied - for details see FAOSTAT) with regard to production, import and export. This identification is very important as it provides the data for the modified BCG matrix creation, and also for competitiveness analyses

The paper has analyses the full range of DRC agrarian production and import and export structure. The data are in 1000 I\$ (constant 2011, prices - for international dollar methodology see details provided by WB (2016)), and they can be found in the appendix of the paper. In relation to the above mentioned objectives, the paper identifies 10 the most important products or groups of products produced or traded in the DRC in 2004 and 2012, and the specified production structure is compared to the production structure development typical for the African region. The idea is to identify differences/similarities existing between the DRC and the rest of the African region.

Using the production, import and export data collected from the above analysis, a modified BCG matrix is done to determine which products should be abandoned as they are unproductive (miserable dogs), which ones request more funding as they show a big income potential (stars), which ones request less funding and income collection due to maturity (dairy cows), which ones are in the starting mode where the DRC should pay more attention as they are not sure whether to grow or to die (question-marks).

The analysis of the BCG has been processed as in Figure 1:

\begin{tabular}{|c|c|c|}
\hline $\begin{array}{ll}\text { BCG } & \text { DRC } \\
2004 & \\
\end{array}$ & $\leftarrow$ vs. $\rightarrow$ & $\begin{array}{ll}\text { BCG } & \text { DRC } \\
2012 & \\
\end{array}$ \\
\hline$\uparrow$ & & $\uparrow$ \\
\hline vs. & & vs. \\
\hline$\downarrow$ & & $\downarrow$ \\
\hline $\begin{array}{l}\text { BCG AFRICA } \\
2004\end{array}$ & $\leftarrow \quad$ VS. & $\begin{array}{l}\text { BCG AFRICA } \\
2012\end{array}$ \\
\hline
\end{tabular}

Source: FAOSTAT, own processing, 2016

Figure 1: BCG analysis model DRC versus Africa (2004 and 2012).

The BCG matrix (Palia A et al. 2002) originates from the consultancy firm Boston Consulting Group. This is an important marketing tool which allows users to concentrate their capabilities (finance, human resources, etc.) to develop only those products that are important and beneficial to them. More specifically, this matrix determines which products are in each of the following four categories:

- Question-marks: these are the products which are at the beginning of their life cycle. They can become promising products which are then converted into stars or they might not succeed and turn to miserable dogs. The BCG matrix user should be very careful while dealing with these products.

- Stars: these products have a market share which is considerable and they are growing quickly. They deserve more funding to return more revenue.

- Dairy cows: these products need less funding as they are in the mature stage. There is a need to collect maximum revenue from these products as they will not grow any more, though they still have a high market share. They will eventually turn into miserable dogs. The income collected can then be used to finance the stars and the question-marks if needed.

- Miserable dogs: these products have slow growth and low market share. They should be abandoned.

The modified BCG matrix is based on:

- $\quad$ Rate of growth (value of production, export value and import value)

- Relative share (the share in total agricultural production value, export value and import value)

The rate growth is calculated as the Geometric mean

$\left(\prod_{i=1}^{n} a_{i}\right)^{1 / n}=\sqrt[n]{a_{1}, a_{2}, \ldots a_{n}}=$ GEOMEAN

The geometric mean is an average that is used to indicate the central tendency value of a set of numbers by using the product of their values. For this paper, the geometric mean will be used to define the average of the rate of market growth and of the relative market share.

The agricultural market in the DRC is an extremely concentrated one. To analyse production and trade commodity concentration we decided to apply the Herfindahl-Hirschman index (HHI) (Hirschman, 1964). This index is usually applied to analyse the level of market concentration at the level of individual companies sales as a part of total sales 
realized within the market. We decided to apply that index to analyse the level of production and trade concentration/diversification. The HHI is calculated for production value, export value and also import value performance (in 1000 I\$, 2011 constant prices).

$\mathrm{HHI}$ is used to measure the commodity concentration within the market. The index ranges from 0 (no concentration) to 10,000 (absolute level of concentration) (Hirschman, 1964). The index is calculated by squaring the value of individual commodities within the market (production, export, import) and adding the resulting numbers together:

$\mathrm{HHI}=\mathrm{s} 1^{\wedge} 2+\mathrm{s} 2^{\wedge} 2+\mathrm{s} 3^{\wedge} 2+\ldots+\mathrm{sn} \mathrm{n}^{\wedge}$,

where $\mathrm{s} 1$ is the value of selected commodities production, export or import value and , $\mathrm{n}^{\text {“ }}$ represents the whole set of commodities. This article uses the HHI classification defined by the US Department of Justice. If the HHI is lower than 0.01 (or 100), the market concentration is low. HHI ranging from 0.01 and 0.15 (100 and 1,500 respectively) indicates that the market is not concentrated. The values of HHI from 0.15 to 0.25 (1,500 and 2,500 respectively) reveal significant level of concentration and HHI above $0.25(2,500)$ indicates a highly concentrated market (when considering the level of production, export or import commodity structure concentration). If an HHI is close to $1(10,000)$, it suggests a dominancy of only one commodity.

A part of this paper is also the competitiveness analysis based on an application of the Lafay index (LFI). The Lafay index (Lafay, 1992) has the ability to prove the existence of bilateral comparative advantages existing between one country (in our case the DRC) and its trade partner or partners. The LFI helps one to understand how the comparative advantages have developed over time and to compare its strengths for individual products and product groups in individual regions and countries.

For a given country $i$, and for any given product $j$, the Lafay index is defined as:

$$
L F I_{j}^{i}=100\left(\frac{x_{j}^{i}-m_{j}^{i}}{x_{j}^{i}+m_{j}^{i}}-\frac{\sum_{j=1}^{N}\left(x_{j}^{i}-m_{j}^{i}\right)}{\sum_{j=1}^{N} x_{j}^{i}+m_{j}^{i}}\right) \frac{x_{j}^{i}+m_{j}^{i}}{\sum_{l=1}^{N} x_{j}^{i}+m_{j}^{i}}
$$

In this equation, $x_{j}^{i}$ and $m_{j}^{i}$ represent exports and imports of product $j$ of country $i$, towards and from a particular region or the rest of the world, respectively, and $N$ is the number of items. Positive values of the Lafay index indicate the existence of comparative advantages in a given item; the larger the value the higher the degree of specialization. (Zaghini, 2003).

\section{Results and discussion}

The agricultural sector of the DRC is changing its character very slowly. Its production structure is based especially on cheap low added-value commodities. The majority of domestic production is not even gained through the market, as it is consumed by the farmers. The extreme level of poverty does not provide any possibility to many people than to produce high volume commodities to feed themselves and their families. It is the reason why the production structure is so limited. Another reason is the effort of government to encourage the farming of cash crops. The main idea is to improve the farmers' income. However, too high a level of cash crops production is also negative for many reasons. The country is focused only on a few commodities. Those commodities are extremely specific and their price fluctuates widely. The result of cash crops farming is an even higher agricultural sector and market destabilization. The country is becoming more and more dependent on bulk commodities imports, and income from cash crops are not able to cover the constantly increasing imports.

Commercial agriculture in the country is relatively limited as most producers are small-scale farmers and subsistence food producers, because of the deterioration of the market infrastructure caused by war. The main agricultural products in terms of volume and value are: cassava, plantains, game meat, maize, groundnuts, rice, mangoes, and mangosteens. The main agricultural exports in terms of value are unmanufactured tobacco, green coffee, sugar raw centrifugal, wheat bran, and natural dry rubber. The main agricultural imports in terms of value are wheat, maize, wheat flour, palm oil and chicken meat (PNIA, 2014).

Agricultural production is changing rapidly in the DRC. Individual changes are affected by re-structuring the DRC economy. Only in the period 2004 - 2012 (last available verified data), the agriculture sector recorded the following changes affecting its production and also trade portfolio. In the analysed time period the value of agricultural production increased from cc 3.7 billion I\$ up to cc 4.1 I\$. The average inter-annual production growth rate recorded the value of $1.1 \%$. The production profile 
significantly changed. The changes are apparent especially if we compare the DRC production profile development to the African region production profile development.

While the African production profile is quite heterogeneous (see Table ANNEX 1), the DRC production profile is very limited (Table 1). About $80 \%$ of the production profile is represented by only a few commodities. About fifteen commodities represented in 2004 cc $80 \%$ of the production profile, whilst in 2012 the $80 \%$ of production profile was made up of about 20 commodities.

If we compare the African portfolio and the DRC production portfolio we can see that the DRC situation is extremely limited. Only three commodity items represent over 50\% of total production performance. Such trade structure makes the DRC extremely vulnerable if any crises or price fluctuation were to appear. The limited production heterogeneity also makes the DRC extremely dependent on exports and imports. In comparison to other African countries the DRC commodity profile is extremely narrow. In 200446 production items represented $80 \%$ of African production value performance in the DRC, the same $80 \%$ was reached by only 16 items. Later in 2012 the situation became a little bit better, but still the DRC is a long way from the majority of African countries. About $80 \%$ of production profile is based on only 20 items, while the average for the whole African region is about 50 items.

Another significant problem affecting production performance is the limited production rate of the DRC in comparison to the rest of Africa. While in Africa the production growth is between $2 \%$ and $3 \%$ a year, in the DRC it is only cc $1 \%$ (while the human population growth rate is over $3 \%$ ).

The main pillars of the DRC production volume, and value profile in particular, are the low addedvalue commodities such as cassava, plantains, game meat and groundnuts, maize and palm oil. Despite huge effort by local farmers, the government, and also external (foreign) partners, the DRC is not able to change its production profile and the situation is even worsening - especially

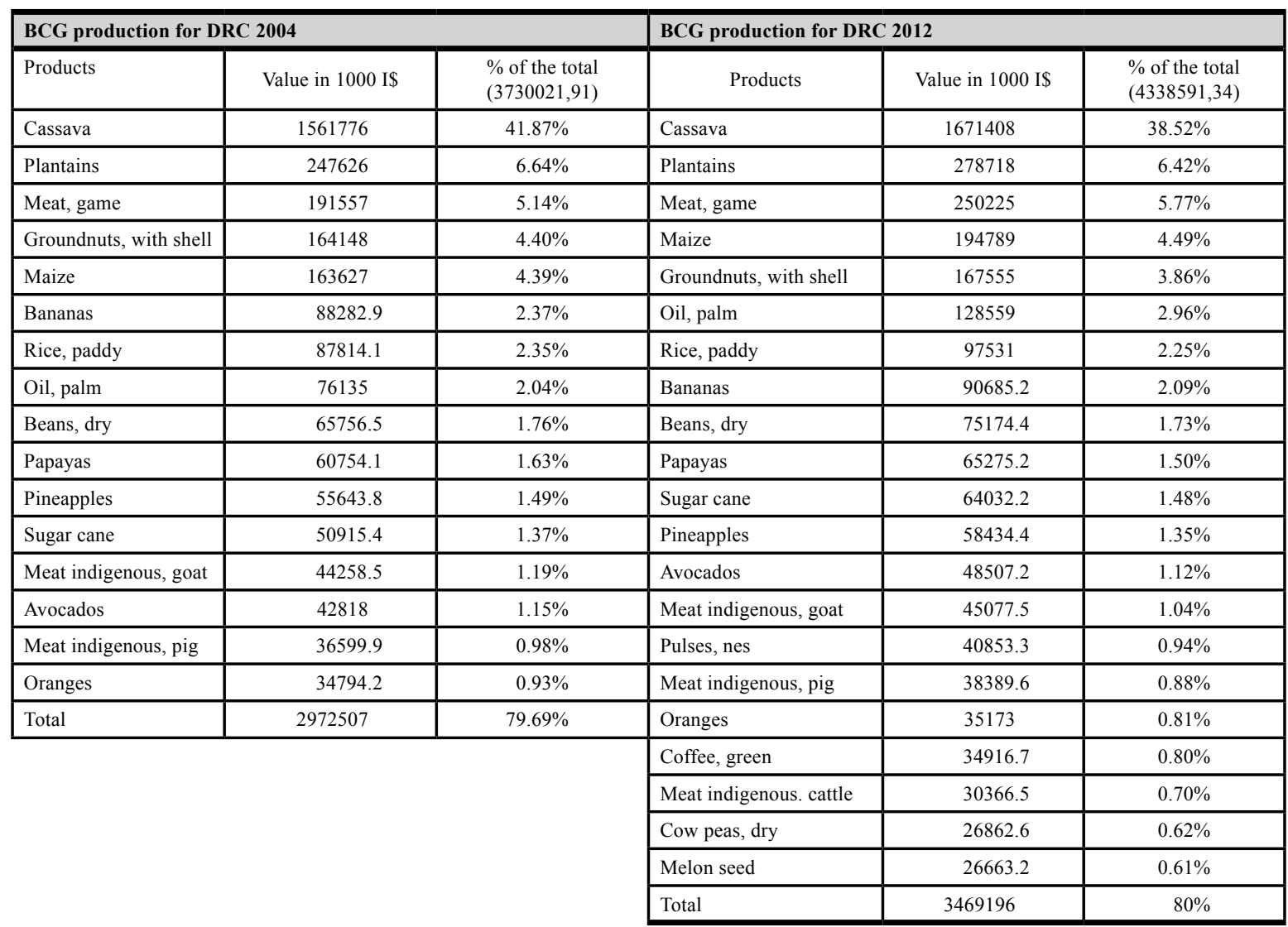


because of the constantly running process of reducing the average farm size.

\section{DRC agrarian trade}

In the past the DRC was considered to be a very strong agricultural production exporter. Over the last four decades, however, development trends have turned the country into a net importing country, suffering because of the steadily-growing negative trade balance value. Only in period 2004 - 2012 the value of imports increased by cc 800 million I\$, while the value of exports increased by only cc 46 million I\$. The DRC is more and more dependent on imports of many commodity items, including also those items which can be produced even in sufficient quantity directly in the DRC. Details related to DRC agrarian trade performance can be seen in Table 2 .

\section{DRC import}

The agrarian import commodity profile for the DRC is illustrated through the following Table 3. At the foot of Table 3 it can be seen that import commodity profile is even more heterogeneous in comparison to production profile and the inter-annual growth rate of import value profile is much higher in comparison to production value growth. The structure, and especially the growth rate of import value in DRC, is extremely different when compared to other African countries (see the ANNEX 2). The growth rate of import value makes from DRC one of the most importdependent countries in Africa, and it is possible to expect that the situation will become even more critical in the near future - especially because of the constantly growing demand, and also because of possible climate changes.

The main items representing the majority of imports value are the following: wheat, poultry meat, palm oil, sugar, rice and milk. Those items represent nearly $50 \%$ of all imports. The DRC is becoming less and less self-sufficient, especially in the basic agricultural commodities necessary to feed the population. While Africa as a region is becoming more dependent on imports of semifinalised or already finalised agricultural products, the DRC is more and more dependent on import of unprocessed commodities.

If we focus our attention especially on changes in commodity structure - it is possible to observe that import value growth is especially related to commodities for human feeding. This applies in particular to such commodities as wheat $(+221 \%)$, poultry meat $(+269 \%)$, plant oil $(+1100 \%)$, milk $(+150 \%)$, sugar $(+150 \%)$ etc. Imports are more oriented on bulk commodities.

\section{DRC export}

Exports from the DRC (Table 4) are extremely limited. The value (per capita) and inter-annual growth rate are below the regional average. The commodity structure is extremely concentrated onto only a few items representing the majority of export performance. As already mentioned, before the current export performance was only 46 million I\$ and $80 \%$ of trade performance was represented by only 10 items. Agrarian export commodity structure is based especially on tobacco, green coffee, rubber, cocoa, palm oil kernel and palm oil. During approximately the last ten years, the export structure has changed slightly. It is possible to see the reduction of maize, sugar and wheat exports - commodities necessary for population feeding. On the other hand exports now are more focused on cash crops commodities in particular. These commodities are profitable, but on the other hand, the high attention on cash crops commodities makes the DRC economy and agriculture even more dependent on the external environment. The high orientation on cash crops is

\begin{tabular}{|c|c|c|c|c|c|c|c|c|c|c|}
\hline \multicolumn{11}{|c|}{ Import Value (1000 I\$) } \\
\hline item & 2004 & 2005 & 2006 & 2007 & 2008 & 2009 & 2010 & 2011 & 2012 & Growth rate \\
\hline $\begin{array}{l}\text { Agricult. } \\
\text { Products }\end{array}$ & 328808 & 433581 & 452890 & 650355 & 655909 & 801458 & 996727 & $\begin{array}{c}1007 \\
293\end{array}$ & 1108127 & 1164008 \\
\hline \multicolumn{11}{|c|}{ Export Value (1000 I\$) } \\
\hline item & 2004 & 2005 & 2006 & 2007 & 2008 & 2009 & 2010 & 2011 & 2012 & Growth rate \\
\hline \multicolumn{11}{|c|}{ Trade Balance Value (1000 I\$) } \\
\hline item & 2004 & 2005 & 2006 & 2007 & 2008 & 2009 & 2010 & 2011 & 2012 & Growth rate \\
\hline $\begin{array}{l}\text { Agricult. } \\
\text { Products }\end{array}$ & -307247 & -395213 & -418972 & -610881 & -613912 & -742244 & -935168 & -929166 & -1039747 & $\mathrm{XX}$ \\
\hline
\end{tabular}

Source: FAOSTAT, own processing, 2016

Table 2: DRC Agricultural trade development. 


\begin{tabular}{|c|c|c|c|c|c|}
\hline \multicolumn{3}{|c|}{ BCG production for DRC 2004} & \multicolumn{3}{|c|}{ BCG production for DRC 2012} \\
\hline Products & Value in $1000 \mathrm{I \$}$ & $\begin{array}{l}\% \text { of the total } \\
(433581,00)\end{array}$ & Products & Value in $1000 \mathrm{I \$}$ & $\begin{array}{l}\% \text { of the total } \\
(1172019,00)\end{array}$ \\
\hline Rice & 59764 & $13.78 \%$ & Wheat & 147942 & $12.62 \%$ \\
\hline Wheat & 46057 & $10.62 \%$ & Poultry Meat & 117568 & $10.03 \%$ \\
\hline Meat. chicken & 31831 & $7.34 \%$ & Oil. palm & 102000 & $8.70 \%$ \\
\hline Milk. whole dried & 28042 & $6.47 \%$ & Beverages & 61587 & $5.25 \%$ \\
\hline Flour. maize & 23000 & $5.30 \%$ & Sweeteners and Honey & 61150 & $5.22 \%$ \\
\hline Sugar Raw Centrifugal & 19089 & $4.40 \%$ & Rice & 53381 & $4.55 \%$ \\
\hline Cigarettes & 16708 & $3.85 \%$ & Oil. olive residues & 41765 & $3.56 \%$ \\
\hline Pulses & 13385 & $3.09 \%$ & Milk Dry & 36289 & $3.10 \%$ \\
\hline Malt & 7940 & $1.83 \%$ & Milk. whole dried & 34905 & $2.98 \%$ \\
\hline Oil. palm & 7730 & $1.78 \%$ & Sugar refined & 29483 & $2.52 \%$ \\
\hline Oil. rapeseed & 7600 & $1.75 \%$ & Malt & 26788 & $2.29 \%$ \\
\hline Beans. dry & 6800 & $1.57 \%$ & Pigmeat & 22467 & $1.92 \%$ \\
\hline Meat. cattle & 6500 & $1.50 \%$ & Tobacco & 21646 & $1.85 \%$ \\
\hline Tomatoes. paste & 6265 & $1.44 \%$ & Meat. turkey & 20611 & $1.76 \%$ \\
\hline Oil. sunflower & 4700 & $1.08 \%$ & Pulses & 18580 & $1.59 \%$ \\
\hline Eggs. hen. in shell & 3613 & $0.83 \%$ & Rapeseed & 17400 & $1.48 \%$ \\
\hline Beverages. distilled alcoholic & 3495 & $0.81 \%$ & Oil. rapeseed & 17400 & $1.48 \%$ \\
\hline Margarine. short & 3037 & $0.70 \%$ & Meat. pig & 12266 & $1.05 \%$ \\
\hline Peas. dry & 3000 & $0.69 \%$ & Beans. dry & 11813 & $1.01 \%$ \\
\hline Cheese and Curd & 1650 & $0.38 \%$ & Cotton lint & 8700 & $0.74 \%$ \\
\hline Beverages. non- alcoholic & 1634 & $0.38 \%$ & Peas. dry & 6452 & $0.55 \%$ \\
\hline Onions. dry & 1452 & $0.33 \%$ & Oil. soybean & 5600 & $0.48 \%$ \\
\hline Onions & 1452 & $0.33 \%$ & Maize & 4427 & $0.38 \%$ \\
\hline Flour. potatoes & 1400 & $0.32 \%$ & Butter & 4169 & $0.36 \%$ \\
\hline Pigmeat & 1226 & $0.28 \%$ & Cheese and Curd & 3582 & $0.31 \%$ \\
\hline Butter & 1221 & $0.28 \%$ & Garlic & 3565 & $0.30 \%$ \\
\hline Tea & 1188 & $0.27 \%$ & Margarine. short & 3138 & $0.27 \%$ \\
\hline Total & 309779 & $71.45 \%$ & Total & 922010 & $76.34 \%$ \\
\hline
\end{tabular}

Source: FAOSTAT, own processing, 2016

Table 3: DRC: Agrarian import commodity structure.

\begin{tabular}{|l|c|c|l|c|c|}
\hline BCG production for DRC 2004 & \multicolumn{1}{l|}{ BCG production for DRC 2012 } \\
\hline Products & Value in 1000 I\$ & $\begin{array}{c}\text { \% of the total } \\
(38368.00)\end{array}$ & \multicolumn{1}{|c|}{ Products } & Value in 1000 I\$ & $\begin{array}{c}\text { \% of the total } \\
(45931.00)\end{array}$ \\
\hline Tobacco. unmanufactured & 9988 & $26.03 \%$ & Coffee. green & 13732 & $29.90 \%$ \\
\hline Coffee. green & 7387 & $19.25 \%$ & Rubber natural dry & 7651 & $16.66 \%$ \\
\hline Sugar Raw Centrifugal & 3737 & $9.74 \%$ & Natural Rubber & 7651 & $16.66 \%$ \\
\hline Maize & 1598 & $4.16 \%$ & Tobacco & 3621 & $7.88 \%$ \\
\hline Cocoa. beans & 1387 & $3.61 \%$ & Cocoa. beans & 2302 & $5.01 \%$ \\
\hline Bran. wheat & 1259 & $3.28 \%$ & Oil. palm kernel & 950 & $2.07 \%$ \\
\hline Rubber natural dry & 1094 & $2.85 \%$ & Oil. palm & 315 & $0.69 \%$ \\
\hline Total & 26450.00 & $68.94 \%$ & Total & 36640.00 & $79 \%$ \\
\hline
\end{tabular}

Source: FAOSTAT, own processing, 2016

Table 4: DRC: Agrarian export commodity structure.

destructive - especially for two reasons. The DRC must import more "conventional" commodities, because it is not possible to feed people with cash crops. The second problem is too high sensitivity of DRC exports and agricultural sector performance in relation to regional and global prices. The commodity structure of DRC exports is extremely different in comparison to other regions and also in relation to the African region (see the Table ANNEX 3). 
If we compare the DRC and the African regions' export portfolios, we can see that the DRC is extremely focused on cash crops commodities. While the African region's exports are based on about 100 commodities representing cc 75\% of African exports (without DRC), the export structure of the DRC is based (as mentioned above) on cc ten aggregations representing almost $80 \%$ of exports value. The paper shows that in 2004 the DRC had 7 products representing $69 \%$ of its total exports. The following list represents the important products in both portfolios in 2004 even though the \% value added is not the same:

i. Maize: 4.16 (DRC) compared to 0.99 (Africa)

ii. Sugar Raw Centrifugal: 9.74 (DRC) compared to 4.02 (Africa)

iii. Coffee, green: 19.25 (DRC) compared to 3.88 (Africa)

iv. Cocoa, beans: 3.61 (DRC) compared to 15.02 (Africa)

v. Tobacco, unmanufactured: 26.03 (DRC) compared to 4.49 (Africa)

vi. Rubber natural dry: 2.85 (DRC) compared to 1.72 (Africa)

The following list represents important products in both portfolios in 2012 even though the \% value added is not the same:

i. Wheat: 0.25 (DRC) compared to 0.21 (Africa)

ii. Maize: 0.17 (DRC) compared to 2.2 (Africa)

iii. Oil, palm: 0.69 (DRC) compared to 1.09 (Africa)

iv. Oil, palm kernel: 2.07 (DRC) compared to 0.28 (Africa)

v. Coffee, green: 29.9 (DRC) compared to 5.05 (Africa)

vi. Cocoa, beans: 5.01 (DRC) compared to 12.42 (Africa)

vii. Tea: 0.41 (DRC) compared to 2.33 (Africa)

viii. Tobacco, unmanufactured: 7.88 (DRC) compared to 6.00 (Africa)

ix. Beverages: 0.08 (DRC) compared to 3.61 (Africa)

Agricultural production and trade segmentation structure analyses; modified BCG matrix applied

\section{BCG quadrants for 2004 compared to 2012}

In the above analysis, the paper identified which products are the most important for the production, import or export portfolios and how each of those portfolio structures changed between 2004 and 2012. Now the following study will make a deeper analysis of each product life cycle, as it is very important for determining business strategies. In this section a BCG matrix will determine the DRC's production and trade structure according to their perspectives for the development growth of future agricultural sectors. The following three sets of BCG matrixes provide an overview of the DRC agricultural production and trade structure. Each segment of the BCG matrix provides an overview about the past and the current situation of DRC agriculture. The idea is to identify the main segments representing the pillars of agricultural production, exports and imports activities. The idea is to identify the most perspective product groups representing the current strengths and future opportunities for DRC agriculture and trade, and on the other hand to identify those commodities representing the current weaknesses and future threats of DRC agricultural sector. The idea is to define some possible recommendations for future agricultural sector development.

\section{Production}

The next part of the paper is focused on identification of production structure perspectives. The BCG matrix provides an opportunity to compare the commodity structure of the DRC agricultural production in 2004 and 2012, and it also provides an opportunity to compare the DRC to the rest of the African region. The BCG matrix provides a possibility to divide a commodity structure into four segments according to individual commodities' share in total production and inter-annual growth rate (for details - see the methodology). The results for DRC can be compared to the rest of the African region. On the basis of the BCG matrix it is possible to specify the following findings. The most perspective segment (stars) is represented by beans, maize cassava, the pillars of production performance are represented by papayas, palm oil, Game meat and bananas. The other commodities can be considered only as question-marks and even dogs - it means they are not perspective at all. The problem of the DRC compared to Africa as a region is the fact that while in Africa the commodity segments called stars and cash cows are improving their position within the commodity structure, in the DRC it is vice versa. Only a few commodity items can be considered as cash cow or even star. On the other hand the share of those commodities in production performance is increasing. The problem is that the production commodity structure is becoming less and less 
heterogeneous, and the DRC is more and more dependent on only a few production items. The commodity segments stars and cash cows have been representing more than $70 \%$ of the production structure, and the share of those two items is constantly increasing. Such a trend would be without any doubts a positive one if the number of items within the cash cow and star segments would not be so low. (The following graph number 1 provides information about the DRC and the African BCG matrix structure development). The DRC stars segment recorded during the analysed time period only marginal changes its share and value changed from $52 \%$ and 1.95billion I\$ to about $50 \%$ and almost 2 billion I\$. While the value is the same, the number of items reduced. In the case of the cash-cow segment it is possible to see the growth of share and value from cc $7 \%$ (about 300 million I\$) to more than $12 \%$ (cc 400 million I\$). Question-marks and dogs have been keeping their share of about $40 \%$ in total production - but the number of items representing the dogs is constantly increasing. The problem of the DRC agricultural production is its constantly reducing heterogeneity of production profile. The DRC is becoming more and more specialised. Unfortunately the specialization process is focused especially on cash crops, and production stability is disappearing.

\section{Import}

While production volume and structure are worsening their position within the market, the import profile is becoming more and more important. In the past DRC import was more or less stabilized, however, nowadays its value and inter-annual growth are increasing. The majority of import items are represented by bulk commodities necessary to import for direct human feeding. While ten years ago the DRC was self-sufficient in many different items, nowadays it is not self-sufficient in any really important bulk agricultural commodity except for cassava. The inter-annual growth rate of import value is about ten-times higher compared to production

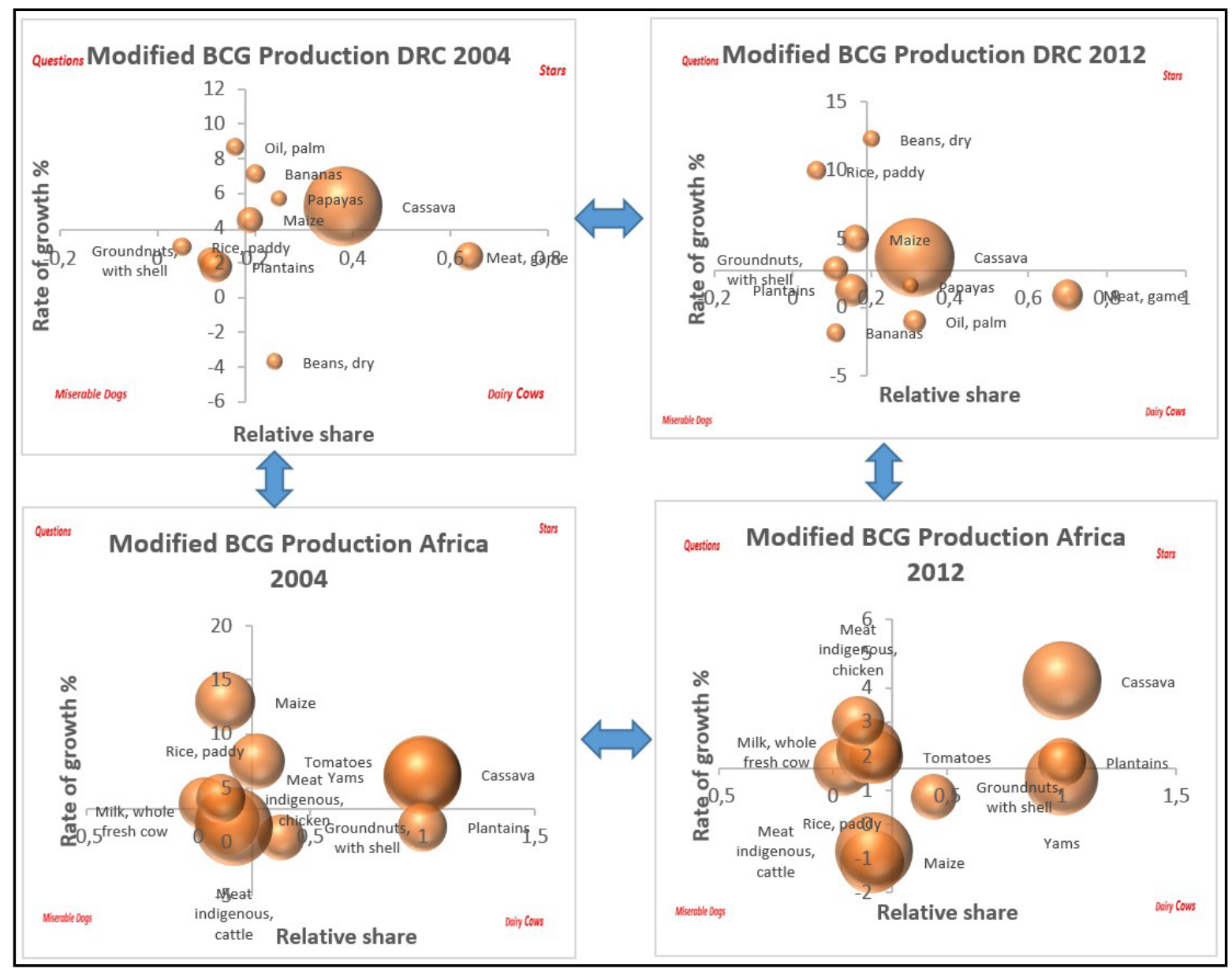

Source: FAOSTAT, own processing, 2016

Graph 1: BCG matrix production model - DRC versus Africa (2004 and 2012). 
value growth. Many items, for example Milk, Meat, Rice, maize, Malt, Flour, Oil, Sugar, are being imported in larger amounts, because of lack of domestic production. The import structure is now completely destabilised - it means that the DRC is looking for a new market balance. Unfortunately the decision of farmers and also government to focus their attention on production of cash crops was not a very successful one, and the country is suffering. In comparison to the rest of the African region, the DRC represents a specific country. Its import structure development is completely different in comparison to the rest of the African region. The problem of the $\mathrm{DRC}$ is its limited ability to finish restructuring its agricultural sector and to make its production structure more heterogeneous. Another problem is the very limited farmers' ability to increase production performance and their production efficiency.

\section{Export}

The export profile of the DRC recorded during the analysed time period has an extremely specific development. The export structure was reduced to only a few commodity items. The majority of bulk commodities almost disappeared and the current export is based from over $70 \%$ on cash crops items. The ability of the DRC to export agricultural products is slowly dispersing. Nowadays, only palm oil kernel can be considered as a star - the rest of the cash-crops items have already lost their dynamics and their turned themselvesinto "cash cows". The export structure currently has almost no question-marks (the possible future export leaders) and the dynamics of cash cows is also diminishing. Nowadays the export structure is based only on maize, rubber, green coffee, cocoa, palm oil kernel and palm oil. Such a limited export

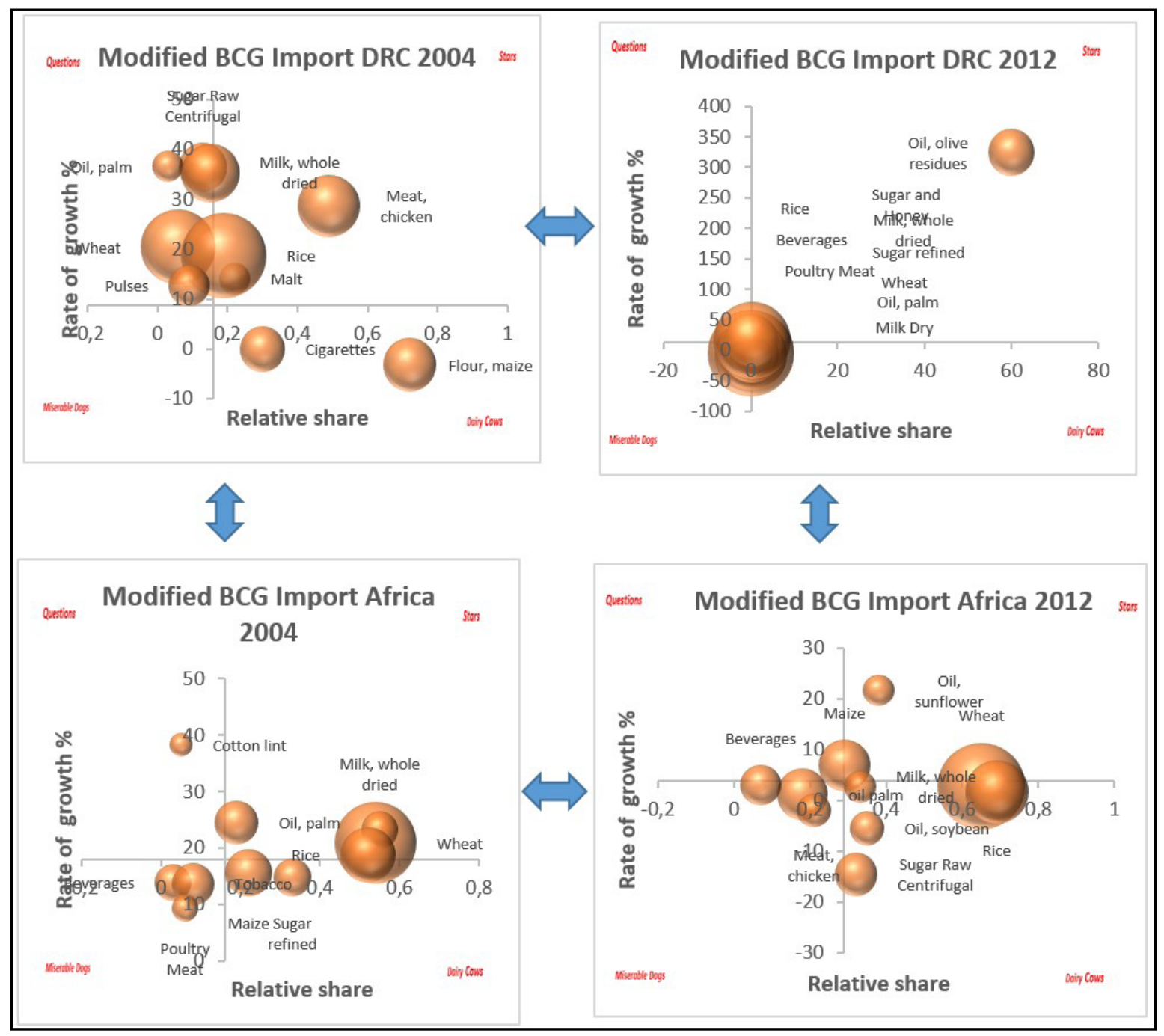

Source: FAOSTAT, own processing, 2016

Graph 2: BCG matrix import model - DRC versus Africa (2004 and 2012). 


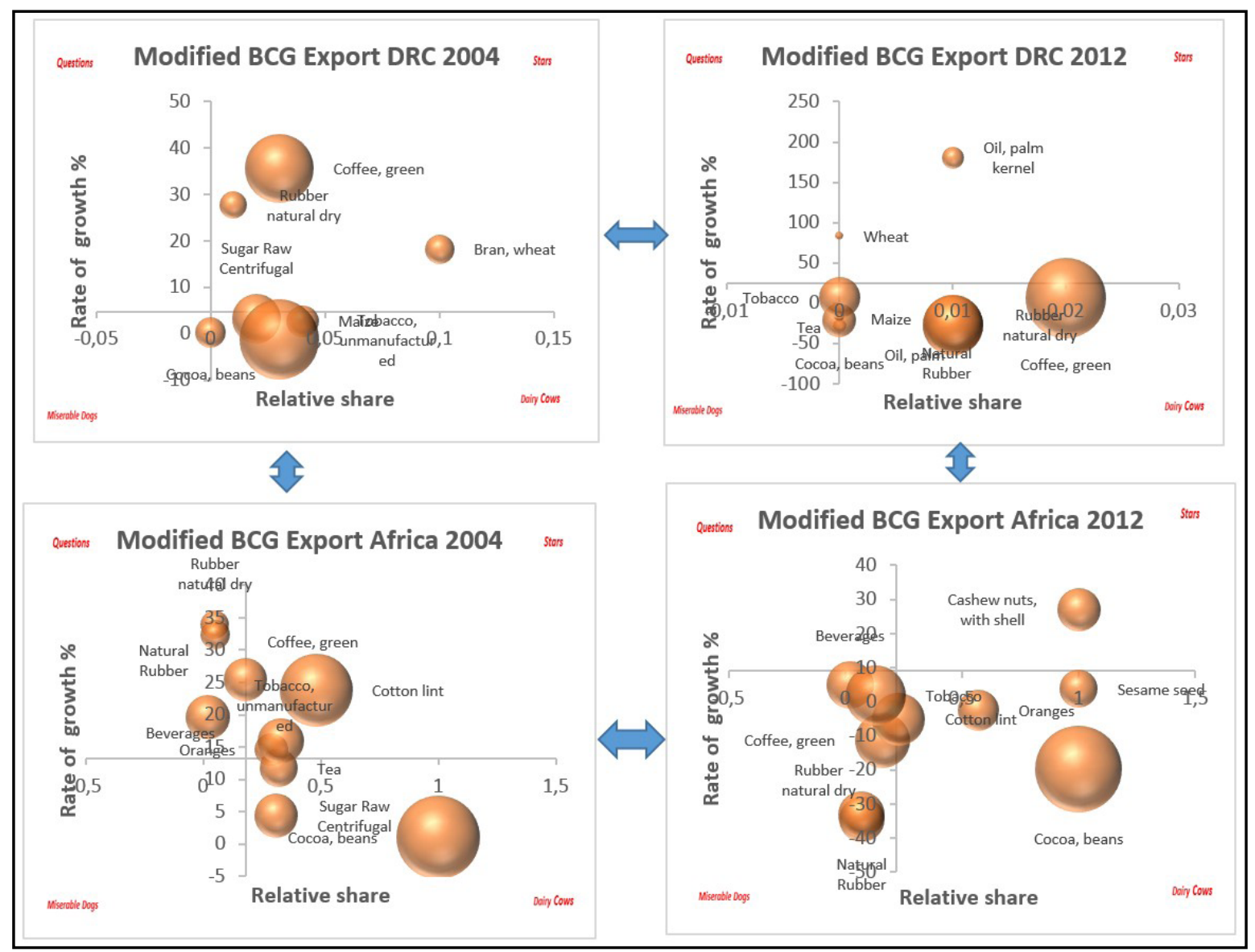

Source: FAOSTAT, own processing, 2016

Graph 3: BCG matrix export model - DRC compared to Africa (2004 and 2012).

profile represents a problem/barrier for the future agricultural sector transformation process. Again if we compare the export structure profile to the African region export profile, it is possible to see that the DRC is in stagnation, and its agricultural market is in crisis. Its ability to generate production for export is marginal (except for certain items) and it is possible to expect that export volume will be reduced even more, particularly because of internal market consumption growth.

Agricultural commodities production and trade concentration; HH index analysis

We have already mentioned that the commodity structure of agricultural production and exports are significantly concentrated in the DRC. The level of agricultural production commodity structure in the DRC is much higher in comparison to the African region. While the $\mathrm{HH}$ index for the African region proved an unconcentrated market, the same HHI calculated for the DRC proved the existence of a significant level of market concentration (for details see the Table 5). A similar result is also coming from the HHI analysis focused on agrarian export commodity concentration. In the case of agrarian exports, the level of commodity concentration in the DRC reached a much higher level in comparison to the African region. The HHI calculation proved the significant concentration of agrarian commodity structure in the DRC. Exports are highly specialised into only a few main commodities. While production and trade structures are quite concentrated in the DRC, the import commodity structure is unconcentrated. The value of the $\mathrm{HH}$ index calculated for the DRC is almost the same as the value of $\mathrm{HH}$ index calculated for Africa as whole region. The low level of import concentration explains the constantly increasing agrarian trade negative balance. The DRC has lost its self-sufficiency, the country is not able to satisfy the increasing demand for food from domestic sources, and the DRC is becoming more and more dependent on imports of many different commodities from other countries. 


\begin{tabular}{|l|c|c|c|c|c|c|c|c|c|}
\hline Production & $\mathbf{2 0 0 4}$ & $\mathbf{2 0 0 5}$ & $\mathbf{2 0 0 6}$ & $\mathbf{2 0 0 7}$ & $\mathbf{2 0 0 8}$ & $\mathbf{2 0 0 9}$ & $\mathbf{2 0 1 0}$ & $\mathbf{2 0 1 1}$ & $\mathbf{2 0 1 2}$ \\
\hline DRC & 0.19 & 0.19 & 0.19 & 0.19 & 0.18 & 0.18 & 0.19 & 0.18 & 0.18 \\
\hline Africa & 0.12 & 0.12 & 0.14 & 0.11 & 0.11 & 0.10 & 0.11 & 0.12 & 0.12 \\
\hline Export & $\mathbf{2 0 0 4}$ & $\mathbf{2 0 0 5}$ & $\mathbf{2 0 0 6}$ & $\mathbf{2 0 0 7}$ & $\mathbf{2 0 0 8}$ & $\mathbf{2 0 0 9}$ & $\mathbf{2 0 1 0}$ & $\mathbf{2 0 1 1}$ & $\mathbf{2 0 1 2}$ \\
\hline DRC & 0.29 & 0.19 & 0.17 & 0.21 & 0.23 & 0.20 & 0.21 & 0.16 & 0.16 \\
\hline Africa & 0.05 & 0.05 & 0.04 & 0.04 & 0.03 & 0.03 & 0.04 & 0.04 & 0.04 \\
\hline Import & $\mathbf{2 0 0 4}$ & $\mathbf{2 0 0 5}$ & $\mathbf{2 0 0 6}$ & $\mathbf{2 0 0 7}$ & $\mathbf{2 0 0 8}$ & $\mathbf{2 0 0 9}$ & $\mathbf{2 0 1 0}$ & $\mathbf{2 0 1 1}$ & $\mathbf{2 0 1 2}$ \\
\hline DRC & 0.07 & 0.06 & 0.06 & 0.09 & 0.050 & 0.050 & 0.05 & 0.05 & 0.05 \\
\hline Africa & 0.04 & 0.05 & 0.05 & 0.05 & 0.055 & 0.065 & 0.05 & 0.05 & 0.05 \\
\hline
\end{tabular}

Source: FAOSTAT, own processing, 2016

Table 5: DRC: Agricultural market concentration (production, export and import commodity structure) - application of HH index (for details see methodology).

Competitiveness analysis based on application of the Lafay index (LFI) for the DRC

The last part of the paper is focused on an analysis of bilateral competitiveness of DRC agricultural trade. The existence of bilateral comparative advantage is analysed through the LFI index (for detail see methodology). The LFI analyses proved that agricultural and food export do not have comparative advantage as a whole group of products. Comparative advantage only exists in the case of a few commodities or commodity sub-groups from the DRC exports. Table 6 provides a brief overview related to the distribution of comparative advantage related to DRC agrarian trade. In 2004 the existence of comparative advantage was proved in the case of the following items: crude materials, coffee, tea, cocoa, tobacco, beverages, sugar, feeding stuff, natural rubber, bananas, plantains and oilseeds. In 2012 the comparative advantage was proved only in the case of tea, cocoa, coffee, crude materials, tobacco, natural rubber, feeding stuff, groundnuts and bananas and plantains. However these items represent the majority of DRC export performance, their share in total production volume and value is very limited and they do not represent the pillar of DRC agriculture.

The number of competitive items in the DRC is extremely small - both if we compare the DRC to the African region average, and also in relation to the global market. Furthermore, the DRC must face another problem, which is the constantly decreasing agricultural trade competitiveness. Just within the last decade the number of items having comparative advantage has decreased by more than $20 \%$.

The weakness of DRC agricultural trade performance is its territorial structure. DRC has been suffering by limited intra-regional trade performance.

\begin{tabular}{|l|c|}
\hline LFI & 2004 \\
\hline Agricult.Products,Total + (Total) & $\mathbf{- 9 4 4 ~ 8 7 3}$ \\
\hline Food Excl Fish + (Total) & $\mathbf{- 1 0 4 ~ 3 6 5}$ \\
\hline Crude Materials -Ex2 + (Total) & 4284168 \\
\hline Tea+Cocoa+Sp + (Total) & 326058 \\
\hline Tobacco + (Total) & 3252651 \\
\hline Beverages+ (Total) & 2950674 \\
\hline Coffee Green+Roast + (Total) & 2862493 \\
\hline Sugar,Total (Raw Equiv.) + (Total) & 0.708069 \\
\hline Fodder \& Feeding stuff + (Total) & 0.467592 \\
\hline Natural Rubber + (Total) & 0.423714 \\
\hline Bananas and plantains + (Total) & 0.005633 \\
\hline Oilseeds + (Total) & 0.001451 \\
\hline LFI & 2012 \\
\hline Food Excl Fish + (Total) & $\mathbf{- 4 . 6 0 2 9 9 7 0 1 9}$ \\
\hline Agricult.Products.Total + (Total) & $\mathbf{- 9 . 4 7 6 8 7 7 5 3 6}$ \\
\hline Tea+Cocoa+Sp + (Total) & 5.668661194 \\
\hline Coffee Green+Roast + (Total) & 2.477173779 \\
\hline Crude Materials -Ex2 + (Total) & 2.016051798 \\
\hline Tobacco + (Total) & 0.481661106 \\
\hline Natural Rubber + (Total) & 0.419905462 \\
\hline Fodder \& Feeding stuff + (Total) & 0.355206283 \\
\hline Groundnuts Total Shelled + (Total) & 0.007215298 \\
\hline Bananas and plantains + (Total) & 0.002071607 \\
\hline Souree FAOSTAT, ow pres \\
\hline
\end{tabular}

Source: FAOSTAT, own processing, 2016

Table 6: DRC: Agrarian trade competitiveness analysis (LFI index).

On the other hand it is heavily dependent on inter-regional trade. The low intensity of intra-regional trade is not problem only for DRC, but it is the significant problem for the whole Africa as region. DRC agrarian trade is focused especially on European countries. Only in 2012 the European Union exported to DRC agricultural and foodstuff products in value about 258 mil. EUR and the value of imports coming from DRC to the EU was about 64 mil. EUR (European 
Commission, 2016). European Union represented more than seventy percent of total DRC agricultural trade performance (both export and import). Such high level of trade territorial structure concentration makes DRC extremely vulnerable and sensitive in relation to any kind of global market shock.

\section{Conclusion}

The role of the agricultural sector in the DRC is an extremely important one. According to available data, the agricultural sector makes up $42 \%$ of the current GDP, and it provides job opportunities for about $60 \%$ of the total population. The agricultural sector in the DRC is in deep crisis. Its production and trade capacities are exhausted because of the instability over the last few decades. Production and trade performance are limited, and even more both production and also trade performance are not able to meet the demands of a constantly increasing population. DRC production growth is very limited and its interannual growth is even lower in comparison to population growth. The constantly increasing domestic demand for food products is also affecting the country's export capacities. The value and inter-annual growth rate of exports are stagnating and the country is becoming more and more dependent on imports. This results in a constantly increasing negative trade balance. The commodity structure of agricultural production is affected by two factors - the first one is the effort to feed the population, the second one is to increase farmers' income. But unfortunately both factors are negatively affecting the agricultural structure and volume performance. The need to feed their extremely poor population resulted in limited production structure, based especially on low price commodities available for the local population. The effort to increase farmers' income encouraged the growth of cash crops production - but cash crops are related to price fluctuation and too high a level of cash crops production, and trade makes the country extremely vulnerable. The DRC agricultural sector is underdeveloped not only in comparison to the developed or transitional countries, but the DRC is also underdeveloped in relation to majority of other African countries. Agrarian production and trade structure have been stagnating and the country is not able to start its agrarian sector transformation process.

The portfolio analysis proved that in 2004 the major part of the production of the DRC was held by only 16 commodities which represented $80 \%$ (in comparison to 21 products in 2012) of the total production of the country. This should be compared to Africa as a region, which had a production portfolio of 46 products forming $80 \%$ of its total production in 2004 (in comparison to 49 products in 2012). This production of the DRC represented only $2 \%$ of the $80 \%$ production of Africa in both 2004 and 2012.

With regard to imports, the DRC had a portfolio of 27 products representing $71 \%$ of its total import in 2004 (in comparison to 49 products representing $79 \%$ in 2012). This should be compared to Africa, which had a portfolio of 106 products representing $69 \%$ of its total import (in comparison to 126 products representing $71 \%$ in 2012), and the imports of the DRC in both years represented $1.5 \%$ of the African import portfolios. Concerning export portfolios, the DRC had a portfolio of 7 products representing $69 \%$ of its total export in 2004 (in comparison to 11 products representing $80 \%$ in 2012), compared to Africa which had a portfolio of 94 products representing $74 \%$ of its total export (in comparison to 127 products representing $79 \%$ in 2012). The export value of the DRC represented $0.2 \%$ of the $74 \%$ African export value in 2004 and $0.1 \%$ of the $79 \%$ African export value in 2012 .

The competitiveness analysis proved the low ability of the DRC to compete in the global market. The number of competitive items is very low and the number is constantly decreasing. Currently there are only a few items which are still competitive: tea, cocoa, coffee, crude materials, tobacco, natural rubber, feeding stuff, groundnuts and bananas and plantains.

DRC agriculture is suffering especially because of low economy transformation level, and also because the position of agriculture within the economy is too strong. To improve the agricultural sector performance it is necessary to encourage the growth of the industrial and services sectors, in particular. It is necessary to move people outside of agriculture and to start agricultural sector transformation. Transformation must be based on massive capital inflow, reduction of farmers and number of farms, and increasing the average farm size. There are other recommendations but they will be the topic of another paper.

\section{Acknowledgement}

The paper is processed within the project IGA, PEF, 20151016 - Establishing food security for Bangladesh's rural poor through sustainable collective farming practices. 
Corresponding author:

Ing. Jean-Paul Ejiba Lubanda

Department of Economics, Faculty of Economics and Management

Czech University of Life Sciences Prague, Kamýcká 129, 16521 Praha 6-Suchdol, Czech Republic

E-mail: Ejiba.lubanda@gmail.com

Orcid ID: orcid.org/0000-0002-7693-6652

Corresponding author:

Doc. Ing. Lubos Smutka, Ph.D.

Department of Economics, Faculty of Economics and Management

Czech University of Life Sciences Prague, Kamýcká 129, 16521 Praha 6-Suchdol, Czech Republic

E-mail:smutka@pef.czu.cz

Orcid ID: orcid.org/0000-0001-5385-1333

\section{References}

[1] Ahmed, A. D.and Suardi, S. (2009) "Macroeconomic Volatility, Trade and Financial Liberalization in Africa", World Development, Vol. 37, No. 10, pp. 1623-1636. ISSN 0305-750X. DOI: $10.1016 /$ j.worlddev.2009.03.009.

[2] Akokpari , J. K. (2001) "The debt crisis, the global economy and the challenges of development: sub Saharan Africa at the crossroads", Journal of Social Development in Africa, Vol. 16, No. 2, pp. 147-170. ISSN 1012-1080. DOI: 10.4314/jsda.v16i2.23877.

[3] DRC, Naip. (2014) "Democratic republic of Congo Agriculture Investment opportunities brief". [Online]. Available: http://www.abghq.com/downloads/DRC.pdf [Accessed: 24 Jun. 2015].

[4] European Commission. (2016) "European Union, Trade in goods with Congo (Democratic Rep". [Online]. Available: http://trade.ec.europa.eu/doclib/docs/2011/january/tradoc_147251.pdf [Accessed 1 June 2015].

[5] FAO. (2010) “The State of Food and Agriculture”. FAO, Roma. ISBN 978-92-5-105980-4.

[6] Food and Agriculture Organization of the United (2016) Faostat. [Online]. Available: http://faostat3.fao.org/ [Accessed 12 Oct. 2015].

[7] Fosu, A. (2001) “The Global Setting and African Economic Growth", Journal of African Economies, Vol. 10, No. 3, pp. 282-310. ISSN 0963-8024. DOI: 10.1093/jae/10.3.282.

[8] Fosu, A. (2003) "Political Instability and Export Performance in Sub-Saharan Africa", Journal of Development Studies, Vol. 39, No. 4, pp. 68-83. ISSN 0022-0388. DOI: 10.1080/713869426.

[9] Fuchs, V. (2013) “The Gross Domestic Product and Health Care Spending", The New England Journal of Medicine. [Online] Available: http://www.nejm.org/doi/full/10.1056/NEJMp1305298 [Accessed: 2 Jan. 2016]. DOI: 10.1056/NEJMp1305298

[10] Global EDGE (2014) "Democratic Republic of the Congo: Economy", Michigan State University, [Online]. Available: http://globaledge.msu.edu/countries/democratic-republic-of-the-congo/ economy [Accessed: 28 Dec. 2015].

[11] Hirschman, A. O. (1964) "The Paternity of an Index". The American Economic Review (American Economic Association), Vol. 54, No. 5, pp. 761. [Online]. Available: http://grundrisse.org/copyright_ violations/Paternity_of_an_Index.pdf[Accessed: 2 Mar. 2016]. ISSN 00028282.

[12] Hopkins, A. (2014) "An Economic History of West Africa". Routledge. [Online] Available: https://books.google.cz/books?hl=cs\&lr=\&id=F_DfBgAAQBAJ\&oi=fnd\&pg=PP1 $\& d q=a$ frica + agriculture $\&$ ots $=$ KKjSGdBt5 $x \& s i g=u l E Y 8 O D W y 17$ S20BN3 wzOI0gzM5o $\&$ redir_esc $=\mathrm{y} \# \mathrm{v}=$ onepage $\& \mathrm{q}=$ africa\%20agriculture $\& \mathrm{f}=$ false $\quad$ [Accessed: 2 Jan. 2016]. ISBN 978-0-582-64521-9

[13] Jeníček, V. (2010) "Population Problem in the Future - Challenges, Questions", Agricultural Economics-Zemedelska Ekonomika, Vol. 56, No. 3, pp. 97-107. ISSN 0139-570X. 
[14] Jeníček, V. (2010) "World Population - Development, Transition", Agricultural EconomicsZemedelska Ekonomika, Vol. 56, No. 1, pp. 1-15. ISSN 0139-570X.

[15] Jeníček, V. (2011) "Developing Countries: Trends, Differentiation”, Agricultural EconomicsZemedelska Ekonomika, Vol. 57, No. 4, pp. 175-187. ISSN 0139-570X.

[16] Kuna, Z. (2010) "Demografický a potravinový problém světa" (Demographic and food world problem - in Czech), Wolters Kluwer, ISBN 978-80-7357-588-5.

[17] Lafay, G. (1992) "The measurement of revealed comparative advantages". In: DAGENAIS, M. G. and MUET, P. A. (eds.)", London: International Trade Modeling, Chapman \& Hill, pp. 209-234. ISBN: 10: 0412450003. 0-412-45000-3.

[18] Maitah, M. and Smutka, L. (2012) "Economic analysis of milk production and consumption in the Middle East and North Africa", Acta Universitatis Agriculturae et Silviculturae Mendelianae Brunensis, Vol. 60, No. 4, pp. 245-254. ISSN 1211-8516. DOI: 10.11118/actaun201260040245.

[19] Maitah, M., Hodrab, R. and Melad, A. (2014) "The impact of quality management practices on firm's performance an empirical investigation of associated constructs in Palestinian information and communication technology firms", International Business Management, Vol. 8, No. 6, pp. 12-326. ISSN 1993-5250. DOI: 10.3923/ibm.2014.312.326.

[20] Maitah, M. and Urbankova, E. (2015) "The effect of educational level on the productivity in the Czech Republic", Modern Applied Science, Vol. 9, No. 6, pp. 226-233. ISSN 1913-1844. DOI: $10.5539 /$ mas.v9n6p226.

[21] Mikhalkina, E., Maitah, M. and Šrédl, K. (2015) "Measuring market structures in the dairy market in the Czech Republic", Asian Social Science, Vol. 11, No. 21, pp. 306-315. ISSN 1911-2017. DOI : $10.5539 /$ ass.v11n21p306.

[22] Ministry of Agriculture of DRC (2012) "Programme spéciale de la relance Agricole pour la prevention de la crise alimentaire". [Online]. Available: http://www.rdc-agriculture.com/index. php?option $=$ com_rubberdoc\&view $=$ category\&id $=68 \&$ Itemid $=66$. [Accessed: 26 Jun. 2016].

[23] Palia, A., De Ryck, J. and Mak, W. K. (2002) "Interactive Online Strategic Market Planning with the Web-Based Boston Consulting Group (BCG) Matrix Graphics Package". Developments in Business Simulation and Experiential Learning. [Online]. Available https://journals.tdl.org/absel/ index.php/absel/article/view/765 [Accessed: 3 Jan. 2016].

[24] Smutka, L. (2011) "Vývoj a struktura agrárního zahraničního obchodu zemí Visegrádské skupiny $\mathrm{v}$ posledních dvaceti letech (Development and structure of agrarian foreign trade of Visegrad countries during the last twenty years - in Czech)“. Prague: Powerprint, -- p. 208. ISBN 978-80-87415-28-3.

[25] Smutka, L. and Tomšík, K. (2011) "Selected aspects of GDP value and structure development in sub-Saharan Africa", Acta Universitatis Agriculturae et Silviculturae Mendelianae Brunensis, Vol. 59, No. 7, pp. 347-362. ISSN 1211-8516. DOI: 10.11118/actaun201159070347

[26] Smutka, L., Tomšík, K. (2014) "GDP Structure and Economic Performance in Sub-Saharan Countries", Acta Universitatis Agriculturae et Silviculturae Mendelianae Brunensis, Vol. 62, No. 4, pp. 729-747. ISSN 1211-8516. DOI: 10.11118/actaun201462040729.

[27] The World Bank (2016) [Online]. Available: http://data.worldbank.org/country/congo-dem-rep [Accessed: 24 Jun. 2012].

[28] Tomšík, K. and Smutka, L. "Selected aspects and specifics of the economic development in sub-Saharan Africa", Acta Universitatis Agriculturae et Silviculturae Mendelianae Brunensis, Vol. 61, No. 2, pp. 517-528. ISSN 1211-8516. DOI: 10.11118/actaun201361020517.

[29] Toth, D., Maitah, M. and Stefkova, M. (2014) "Comparative research of youth employment in France and the Czech Republic", Research Journal of Applied Sciences, Vol. 9, No. 12, pp. 1009-1015. ISSN 1815-932x. DOI: 10.3923/rjasci.2014.1009.1015. 
[30] USAID. (2016) “Agriculture and Food Security”. [Online]. Available https://www.usaid.gov/ democratic-republic-congo/agriculture-and-food-security [Accessed: 4 Jan. 2016].

[31] Wodon, Q. and Zaman, H. (2010) "Higher Food Prices in Sub-Saharan Africa, Poverty Impact and Policy Responses", World Bank Res Obs, Vol. 25, No. 1, pp. 157-176. Online ISSN 1564-6971. DOI: $10.1093 /$ wbro/lkp018

[32] WORLD BANK (2016) "World development indicators on-line". [Online]. Available: http://data.worldbank.org/data-catalog/world-development-indicators [Accessed: 4 Nov. 2016].

[33] WORLD BANK (2016) “International dollar". [Online]. Available: http://data.worldbank.org/ indicator/NY.GDP.PCAP.PP.KD [Accessed: 4 June 2016].

[34] Zaghini, A. (2003) "Trade advantages and specialization dynamics in acceding countries", Working paper № 249. Frankfurt am Main, Germany: European central bank, pp. 4-15. 
Annex

\begin{tabular}{|c|c|c|c|c|c|}
\hline \multicolumn{3}{|l|}{ Production Africa 2004} & \multicolumn{3}{|l|}{ Production Africa 2012} \\
\hline Products & Value in 1000 IS & $\begin{array}{c}\% \text { of the total } \\
(165264156,75)\end{array}$ & Products & $\begin{array}{l}\text { Value in } \\
1000 \text { I\$ }\end{array}$ & $\begin{array}{l}\text { \% of the total } \\
\text { (211916605.74) }\end{array}$ \\
\hline Meat indigenous, cattle & 11816534 & $7.15 \%$ & Cassava & 15295669 & $7.22 \%$ \\
\hline Yams & 11533146 & $6.98 \%$ & Meat indigenous, cattle & 14707901 & $6.94 \%$ \\
\hline Cassava & 11506552 & $6.96 \%$ & Yams & 13161599 & $6.21 \%$ \\
\hline Tomatoes & 5910214 & $3.58 \%$ & Rice, paddy & 8024907 & $3.79 \%$ \\
\hline Rice, paddy & 5304311 & $3.21 \%$ & Tomatoes & 6869076 & $3.24 \%$ \\
\hline Plantains & 4741332 & $2.87 \%$ & Meat indigenous, chicken & 6487756 & $3.06 \%$ \\
\hline Meat indigenous, chicken & 4536602 & $2.75 \%$ & Plantains & 5678493 & $2.68 \%$ \\
\hline Bananas & 3304518 & $2.00 \%$ & Wheat & 3897878 & $1.84 \%$ \\
\hline Sorghum & 3217467 & $1.95 \%$ & Sorghum & 3423242 & $1.62 \%$ \\
\hline Sugar cane & 2933201 & $1.77 \%$ & Cocoa, beans & 3249059 & $1.53 \%$ \\
\hline Cocoa, beans & 2903240 & $1.76 \%$ & Meat indigenous, goat & 3134487 & $1.48 \%$ \\
\hline Cotton lint & 2660611 & $1.61 \%$ & Beans, dry & 3119763 & $1.47 \%$ \\
\hline Millet & 2542382 & $1.54 \%$ & Sugar cane & 3096727 & $1.46 \%$ \\
\hline Meat indigenous, goat & 2510312 & $1.52 \%$ & Cow peas, dry & 2699851 & $1.27 \%$ \\
\hline Grapes & 2194810 & $1.33 \%$ & Olives & 2698933 & $1.27 \%$ \\
\hline Meat, game & 1961523 & $1.19 \%$ & Grapes & 2458442 & $1.16 \%$ \\
\hline Cow peas, dry & 1314708 & $0.80 \%$ & Cashew nuts, with shell & 1787045 & $0.84 \%$ \\
\hline Dates & 1199313 & $0.73 \%$ & Sesame seed & 1758808 & $0.83 \%$ \\
\hline Coffee, green & 1140097 & $0.69 \%$ & Okra & 1750505 & $0.83 \%$ \\
\hline Milk, whole fresh goat & 1130330 & $0.68 \%$ & Dates & 1651379 & $0.78 \%$ \\
\hline Oranges & 1080684 & $0.65 \%$ & Oranges & 1592641 & $0.75 \%$ \\
\hline Okra & 1066083 & $0.65 \%$ & Milk, whole fresh goat & 1413367 & $0.67 \%$ \\
\hline Sweet potatoes & 1051769 & $0.64 \%$ & Sweet potatoes & 1381129 & $0.65 \%$ \\
\hline Cottonseed & 1009430 & $0.61 \%$ & Pineapples & 1183534 & $0.56 \%$ \\
\hline Oil, palm & 930103.1 & $0.56 \%$ & Coffee, green & 1136866 & $0.54 \%$ \\
\hline Cashew nuts, with shell & 906347.2 & $0.55 \%$ & Meat indigenous, buffalo & 1035988 & $0.49 \%$ \\
\hline Milk, whole fresh buffalo & 904149.2 & $0.55 \%$ & Milk, whole fresh buffalo & 1022962 & $0.48 \%$ \\
\hline Apples & 865130.6 & $0.52 \%$ & Oil, palm & 1022786 & $0.48 \%$ \\
\hline Pineapples & 809343.1 & $0.49 \%$ & Apples & 1000774 & $0.47 \%$ \\
\hline Barley & 748382.9 & $0.45 \%$ & Cottonseed & 915129.4 & $0.43 \%$ \\
\hline Meat indigenous, buffalo & 723296.7 & $0.44 \%$ & Tobacco, unmanufactured & 909232.5 & $0.43 \%$ \\
\hline Tobacco, unmanufactured & 721796.1 & $0.44 \%$ & Meat indigenous, camel & 908759.2 & $0.43 \%$ \\
\hline Milk, whole fresh sheep & 717714.6 & $0.43 \%$ & Milk, whole fresh camel & 883920.3 & $0.42 \%$ \\
\hline Sesame seed & 695131.9 & $0.42 \%$ & Milk, whole fresh sheep & 866841.4 & $0.41 \%$ \\
\hline
\end{tabular}

Source: FAOSTAT, own processing, 2016

Table ANNEX 1: African countries agrarian production performance. 


\begin{tabular}{|c|c|c|c|c|c|}
\hline \multicolumn{3}{|l|}{ Production Africa 2004} & \multicolumn{3}{|l|}{ Production Africa 2012} \\
\hline Products & Value in 1000 IS & $\begin{array}{l}\text { \% of the total } \\
(\mathbf{2 8 9 5 4 7 7 5 , 0 0 )}\end{array}$ & Products & $\begin{array}{l}\text { Value in } \\
1000 \text { Is }\end{array}$ & $\begin{array}{l}\text { \% of the total } \\
(84206265,00)\end{array}$ \\
\hline Wheat & 4695454 & $16.22 \%$ & Wheat & 13736493 & $16.31 \%$ \\
\hline Rice & 2138297 & $7.38 \%$ & Rice & 7385791 & $8.77 \%$ \\
\hline Maize & 1564525 & $5.40 \%$ & Maize & 4903091 & $5.82 \%$ \\
\hline Oil, palm & 1337619 & $4.62 \%$ & Oil, palm & 4717764 & $5.60 \%$ \\
\hline Tobacco & 1269573 & $4.38 \%$ & Sugar Raw Centrifugal & 3328613 & $3.95 \%$ \\
\hline Sugar refined & 988226 & $3.41 \%$ & Beverages & 2993008 & $3.55 \%$ \\
\hline Milk, whole dried & 974862 & $3.37 \%$ & Oil, soybean & 2121032 & $2.52 \%$ \\
\hline Beverages & 952998 & $3.29 \%$ & Meat, chicken & 2046217 & $2.43 \%$ \\
\hline Poultry Meat & 496328 & $1.71 \%$ & Milk, whole dried & 1843419 & $2.19 \%$ \\
\hline $\begin{array}{ll}\text { Cotton lint } \\
\end{array}$ & 369303 & $1.28 \%$ & Oil, sunflower & 1782568 & $2.12 \%$ \\
\hline Oil, sunflower & 359291 & $1.24 \%$ & Soybeans & 1365704 & $1.62 \%$ \\
\hline Cattle & 348068 & $1.20 \%$ & Tobacco, unmanufactured & 1031337 & $1.22 \%$ \\
\hline Tomatoes, paste & 330585 & $1.14 \%$ & Tea & 1022151 & $1.21 \%$ \\
\hline Tea & 262407 & $0.91 \%$ & Cattle & 776900 & $0.92 \%$ \\
\hline Soybeans & 255543 & $0.88 \%$ & Coffee, green & 715872 & $0.85 \%$ \\
\hline Malt & 226424 & $0.78 \%$ & Cheese and Curd & 649223 & $0.77 \%$ \\
\hline Coffee, green & 213594 & $0.74 \%$ & Tomatoes, paste & 621450 & $0.74 \%$ \\
\hline Butter & 182086 & $0.63 \%$ & Chocolate products nes & 573333 & $0.68 \%$ \\
\hline Sorghum & 174985 & $0.60 \%$ & Malt & 556645 & $0.66 \%$ \\
\hline Potatoes & 170667 & $0.59 \%$ & Apples & 540218 & $0.64 \%$ \\
\hline Beans, dry & 166660 & $0.58 \%$ & Butter & 518397 & $0.62 \%$ \\
\hline Cheese, whole cow milk & 163797 & $0.57 \%$ & Cheese, whole cow milk & 500508 & $0.59 \%$ \\
\hline Natural Rubber & 146599 & $0.51 \%$ & Barley & 484604 & $0.58 \%$ \\
\hline Margarine, short & 138948 & $0.48 \%$ & Pigmeat & 440801 & $0.52 \%$ \\
\hline Bananas & 127633 & $0.44 \%$ & Potatoes & 388007 & $0.46 \%$ \\
\hline Rubber natural dry & 123071 & $0.43 \%$ & Beans, dry & 330298 & $0.39 \%$ \\
\hline Barley & 119168 & $0.41 \%$ & Rubber natural dry & 305487 & $0.36 \%$ \\
\hline Lentils & 108082 & $0.37 \%$ & Cotton lint & 303698 & $0.36 \%$ \\
\hline Apples & 101661 & $0.35 \%$ & Bananas & 249387 & $0.30 \%$ \\
\hline Meat Sheep Fresh & 81833 & $0.28 \%$ & Sorghum & 248597 & $0.30 \%$ \\
\hline Tallow & 81354 & $0.28 \%$ & Sheep & 227443 & $0.27 \%$ \\
\hline Peas, dry & 68708 & $0.24 \%$ & Lentils & 204127 & $0.24 \%$ \\
\hline Meat, turkey & 67810 & $0.23 \%$ & Eggs, hen, in shell & 192646 & $0.23 \%$ \\
\hline Meat, pig & 57557 & $0.20 \%$ & Meat, turkey & 177834 & $0.21 \%$ \\
\hline Oil, rapeseed & 55375 & $0.19 \%$ & Onions & 159301 & $0.19 \%$ \\
\hline Onions & 54355 & $0.19 \%$ & Groundnuts, shelled & 155346 & $0.18 \%$ \\
\hline Oil, olive, virgin & 54071 & $0.19 \%$ & Peas, dry & 144263 & $0.17 \%$ \\
\hline Eggs, hen, in shell & 52537 & $0.18 \%$ & Chick peas & 133552 & $0.16 \%$ \\
\hline Chick peas & 51947 & $0.18 \%$ & Onions, dry & 129444 & $0.15 \%$ \\
\hline Sesame seed & 48024 & $0.17 \%$ & Dates & 112752 & $0.13 \%$ \\
\hline Goats & 43317 & $0.15 \%$ & Oil, olive, virgin & 102359 & $0.12 \%$ \\
\hline Groundnuts, shelled & 42928 & $0.15 \%$ & Spices, nes & 99521 & $0.12 \%$ \\
\hline Onions, dry & 42828 & $0.15 \%$ & Beet pulp & 96622 & $0.11 \%$ \\
\hline Beet pulp & 39549 & $0.14 \%$ & Almonds shelled & 93153 & $0.11 \%$ \\
\hline Oil, essential nes & 36597 & $0.13 \%$ & Sesame seed & 78527 & $0.09 \%$ \\
\hline Sunflower seed & 32180 & $0.11 \%$ & Cottonseed & 77910 & $0.09 \%$ \\
\hline Spices, nes & 31810 & $0.11 \%$ & Oranges & 76620 & $0.09 \%$ \\
\hline Oranges & 29916 & $0.10 \%$ & Anise, badian, fennel, coriander & 76111 & $0.09 \%$ \\
\hline Cocoa, beans & 27941 & $0.10 \%$ & Horses & 75812 & $0.09 \%$ \\
\hline Pepper (piper spp,) & 26799 & $0.09 \%$ & Whey, dry & 70544 & $0.08 \%$ \\
\hline Dates & 23615 & $0.08 \%$ & Pepper (piper spp,) & 64502 & $0.08 \%$ \\
\hline Whey, dry & 19680 & $0.07 \%$ & Goats & 50180 & $0.06 \%$ \\
\hline Garlic & 15202 & $0.05 \%$ & Garlic & 48930 & $0.06 \%$ \\
\hline Flax fibre and tow & 14593 & $0.05 \%$ & Coconuts, desiccated & 46997 & $0.06 \%$ \\
\hline Cider etc & 13921 & $0.05 \%$ & Grapes & 44661 & $0.05 \%$ \\
\hline Total & & $69.07 \%$ & Total & & $71.45 \%$ \\
\hline
\end{tabular}

Source: FAOSTAT, own processing, 2016

Table ANNEX 1: African countries agrarian production performance. 
Agricultural Production and Trade Structure Profile in Democratic Republic of Congo (DRC)

\begin{tabular}{|c|c|c|c|c|c|}
\hline \multicolumn{3}{|l|}{ Production Africa 2004} & \multicolumn{3}{|l|}{ Production Africa 2012} \\
\hline Products & Value in 1000 IS & $\begin{array}{l}\text { \% of the total } \\
\text { (20511945.00) }\end{array}$ & Products & Value in 1000 IS & $\begin{array}{l}\text { \% of the total } \\
\text { (43224548.00) }\end{array}$ \\
\hline Cocoa, beans & 3080101 & $15.02 \%$ & Cocoa, beans & 5366600 & $12.42 \%$ \\
\hline Cotton lint & 2344091 & $11.43 \%$ & Tobacco & 2594001 & $6.00 \%$ \\
\hline Tobacco, unmanufactured & 920365 & $4.49 \%$ & Coffee, green & 2181749 & $5.05 \%$ \\
\hline Beverages & 852813 & $4.16 \%$ & Cotton lint & 1969783 & $4.56 \%$ \\
\hline Sugar Raw Centrifugal & 823752 & $4.02 \%$ & Beverages & 1559486 & $3.61 \%$ \\
\hline Coffee, green & 795171 & $3.88 \%$ & Natural Rubber & 1482633 & $3.43 \%$ \\
\hline Tea & 624793 & $3.05 \%$ & Rubber natural dry & 1433175 & $3.32 \%$ \\
\hline Oranges & 472587 & $2.30 \%$ & Cashew nuts, with shell & 1332273 & $3.08 \%$ \\
\hline Natural Rubber & 369830 & $1.80 \%$ & Oranges & 1175152 & $2.72 \%$ \\
\hline Rubber natural dry & 352794 & $1.72 \%$ & Sesame seed & 1020856 & $2.36 \%$ \\
\hline Grapes & 315566 & $1.54 \%$ & Tea & 1007380 & $2.33 \%$ \\
\hline Sesame seed & 278302 & $1.36 \%$ & Maize & 950183 & $2.20 \%$ \\
\hline Cashew nuts, with shell & 276801 & $1.35 \%$ & Sugar Raw Centrifugal & 864371 & $2.00 \%$ \\
\hline Rice & 270903 & $1.32 \%$ & Wine & 764494 & $1.77 \%$ \\
\hline Cattle & 255552 & $1.25 \%$ & Grapes & 706640 & $1.63 \%$ \\
\hline Sheep & 222880 & $1.09 \%$ & Pulses & 588871 & $1.36 \%$ \\
\hline Maize & 203918 & $0.99 \%$ & Cheese and Curd & 518261 & $1.20 \%$ \\
\hline Apples & 183491 & $0.89 \%$ & Sheep & 483233 & $1.12 \%$ \\
\hline Bananas & 180848 & $0.88 \%$ & Tomatoes & 474771 & $1.10 \%$ \\
\hline Oil, palm & 166961 & $0.81 \%$ & Oil, palm & 472914 & $1.09 \%$ \\
\hline Pineapples & 127571 & $0.62 \%$ & Cattle & 448221 & $1.04 \%$ \\
\hline Beans, green & 127305 & $0.62 \%$ & Oil, olive, virgin & 415013 & $0.96 \%$ \\
\hline Potatoes & 114895 & $0.56 \%$ & Cheese, processed & 386453 & $0.89 \%$ \\
\hline Olives preserved & 108641 & $0.53 \%$ & Apples & 317653 & $0.73 \%$ \\
\hline Dates & 102840 & $0.50 \%$ & Beans, green & 307657 & $0.71 \%$ \\
\hline Pulses & 96341 & $0.47 \%$ & Wool, greasy & 291057 & $0.67 \%$ \\
\hline Vanilla & 89251 & $0.44 \%$ & Dates & 284720 & $0.66 \%$ \\
\hline Pears & 80807 & $0.39 \%$ & Beans, dry & 269980 & $0.62 \%$ \\
\hline Cheese and Curd & 80550 & $0.39 \%$ & Rice & 265770 & $0.61 \%$ \\
\hline Grapefruit (incl. pomelos) & 80294 & $0.39 \%$ & Onions & 249333 & $0.58 \%$ \\
\hline Wool, greasy & 76576 & $0.37 \%$ & Bananas & 246532 & $0.57 \%$ \\
\hline Onions & 76015 & $0.37 \%$ & Onions, dry & 240944 & $0.56 \%$ \\
\hline Onions, dry & 75294 & $0.37 \%$ & Cloves & 233910 & $0.54 \%$ \\
\hline Tomatoes & 72090 & $0.35 \%$ & Oil, sunflower & 209890 & $0.49 \%$ \\
\hline Lemons and limes & 66388 & $0.32 \%$ & Potatoes & 192221 & $0.44 \%$ \\
\hline Goats & 64120 & $0.31 \%$ & Pears & 161535 & $0.37 \%$ \\
\hline Wheat & 49707 & $0.24 \%$ & Goats & 158878 & $0.37 \%$ \\
\hline Cheese, processed & 49294 & $0.24 \%$ & Groundnuts, shelled & 140579 & $0.33 \%$ \\
\hline Beans, dry & 39987 & $0.19 \%$ & Lemons and limes & 136712 & $0.32 \%$ \\
\hline Plums and sloes & 39701 & $0.19 \%$ & Cheese, whole cow milk & 131808 & $0.30 \%$ \\
\hline Oil, sunflower & 37134 & $0.18 \%$ & Strawberries & 128133 & $0.30 \%$ \\
\hline Cloves & 35839 & $0.17 \%$ & Oil, palm kernel & 119765 & $0.28 \%$ \\
\hline Oil, soybean & 35726 & $0.17 \%$ & Grapefruit (inc. pomelos) & 109821 & $0.25 \%$ \\
\hline Groundnuts, shelled & 35114 & $0.17 \%$ & Soybeans & 105712 & $0.24 \%$ \\
\hline Raisins & 34542 & $0.17 \%$ & Peas, dry & 97951 & $0.23 \%$ \\
\hline Milk, whole dried & 31487 & $0.15 \%$ & Chick peas & 93006 & $0.22 \%$ \\
\hline Meat, game & 28065 & $0.14 \%$ & Wheat & 92733 & $0.21 \%$ \\
\hline Cottonseed & 27808 & $0.14 \%$ & Beet pulp & 80291 & $0.19 \%$ \\
\hline Chillies and peppers, dry & 27388 & $0.13 \%$ & Raisins & 67494 & $0.16 \%$ \\
\hline Chick peas & 25695 & $0.13 \%$ & Avocados & 65373 & $0.15 \%$ \\
\hline Avocados & 21577 & $0.11 \%$ & Plums and sloes & 64832 & $0.15 \%$ \\
\hline Eggs, hen, in shell & 18903 & $0.09 \%$ & Milk, whole dried & 63923 & $0.15 \%$ \\
\hline Rubber, natural & 16818 & $0.08 \%$ & Oil, olive residues & 60553 & $0.14 \%$ \\
\hline Spices, nes & 15666 & $0.08 \%$ & Chillies and peppers, green & 60511 & $0.14 \%$ \\
\hline Chickens & 15660 & $0.08 \%$ & Camels & 58147 & $0.13 \%$ \\
\hline Peas, dry & 14764 & $0.07 \%$ & Peas, green & 49952 & $0.12 \%$ \\
\hline Peaches and nectarines & 13707 & $0.07 \%$ & Peaches and nectarines & 48791 & $0.11 \%$ \\
\hline Strawberries & 13281 & $0.06 \%$ & Spices, nes & 48217 & $0.11 \%$ \\
\hline Camels & 13034 & $0.06 \%$ & Pumpkins, squash and gourds & 43463 & $0.10 \%$ \\
\hline Total & 15264310 & $73.94 \%$ & Total & 34211253 & $78.16 \%$ \\
\hline
\end{tabular}

Source: FAOSTAT, own processing, 2016

Table ANNEX 1: African countries agrarian production performance. 